\title{
PREPARATION AND APPLICATIONS OF SOME COMPLEXES DERIVED FROM LANTHANIDES(III) IONS WITH SOME LIGANDS DERIVED FROM PYRAZOLE
}

\author{
Adel S. Orabi \\ Chemistry Department, Faculty of Science, Suez Canal University, Ismailia, Egypt. \\ orabiadel@hotmail.com
}

The novel complexes derived from some pyrazole derivatives ligands: 2,4-dihydroxybenzylidene3'-imino-5'-methylpyrazole (L1); salicylidene-3'-imino-5'-methylpyrazole (L2); 2-hydroxynaphthylidene3'-imino-5'-methylpyrazole (L3) and $\mathrm{LaCl}_{3}, \mathrm{Ce}\left(\mathrm{NO}_{3}\right)_{3}$ and $\mathrm{Nd}\left(\mathrm{NO}_{3}\right)_{3}$ were prepared and characterized using elemental analysis (C, H, N, M), mass spectrometry, FT-IR spectroscopy, electrical conductivity and thermal gravimetric analysis (DTA/TG).

The electrical conductivity of $0.001 \mathrm{M}$ solutions in DMSO revealed that the electrolytic behavior of all formed complexes as 1:1 (coordination sphere cation : ionization sphere ions) ratio for the complexes derived from L1 and L2 ligands while L3 gave 1:2 electrolyte ratio. The thermal analysis (DTA/TG) of the synthesized complexes revealed the presence of two types of water molecules, one as water of crystallization and the other as coordinated water which acts as a ligand. The complexes could be formulated as $\left[\mathrm{M}(\mathrm{L})_{2} \cdot\left(\mathrm{H}_{2} \mathrm{O}\right)_{\mathrm{n}}\right] \cdot \mathrm{Z} \cdot \mathrm{mH}_{2} \mathrm{O}$ for $\mathrm{L}=\mathrm{L} 1$ and $\mathrm{L} 2,\left[\mathrm{M}(\mathrm{L}) \cdot\left(\mathrm{H}_{2} \mathrm{O}\right)_{\mathrm{n}}\right] \cdot 2 \mathrm{Z} \cdot m_{2} \mathrm{H}_{2} \mathrm{O}$ for $\mathrm{L}=\mathrm{L} 3\left(\mathrm{Z}=\mathrm{Cl}^{-}\right.$for $\mathrm{M}=\mathrm{La}(\mathrm{III})$ and $\mathrm{Z}=\mathrm{NO}_{3}{ }^{-}$for $\mathrm{M}=\mathrm{Ce}(\mathrm{III})$ and $\mathrm{Nd}(\mathrm{III})$ ). The $\mathrm{Nd}(\mathrm{III})-\mathrm{L} 3$ complex exhibits promising catalytic activity towards the aerobic oxidation of $p$-phenylenediamine (PPD) to the corresponding semi-oxidized form $\left(\mathrm{PPD}^{+}\right)$. Furthermore, the antimicrobial activity of the investigated complexes was tested and discussed. The simulated molecular structure and the energy of the formed complexes were performed using the ChemOffice program suite. The relation between the spatial arrangement of the formed complexes and its antimicrobial activity was evaluated.

Keywords: lanthanide(III) solid complexes; catalytic activity; antibacterial properties; thermal and conductivity properties; simulated molecular structure

\section{СИНТЕЗА И ПРИМЕНА НА НЕКОИ КОМПЛЕКСИ НА ЛАНТАНОИД(ІІІ) ЈОНИТЕ СО НЕКОИ ЛИГАНДИ ИЗВЕДЕНИ ОД ПИРАЗОЛ}

Беа синтетизирани и карактеризирани нови комплекси изведени однекои деривати на пиразолот како лиганди: 2,4-дихидроксибензилиден-3'-имино-5'-метилпиразол (L1); салицилиден-3'-имино5'-метилпиразол (L2); 2-хидроксинафтилиден-3'-имино-5'-метилпиразол (L3), со $\mathrm{LaCl}_{3}, \mathrm{Ce}\left(\mathrm{NO}_{3}\right)_{3}$ и $\mathrm{Nd}\left(\mathrm{NO}_{3}\right)_{3}$ кои беа карактеризирани со елементарна анализа $(\mathrm{C}, \mathrm{H}, \mathrm{N}, \mathrm{M})$, масена спектрометрија, FT-IR спектроскопија, електрична спроводливост и термичка гравиметриска анализа (DTA/TG). Електричната спроводливост на 0,001 M раствори во DMSO покажа дека сите образувани комплекси се однесуваат како електролити, и тоа како комплекси од типот 1:1 за комплексите изведени од лигандите L1 и L2, додека комплексите со L3 даваат однос 1:2. Термичката анализа (DTA/TG) на синтетизираните комплекси покажа присуство на два типа молекули на вода, една кристална и една координирана вода која има улога на лиганд. Образуваните комплекси имаат формули од типот $\left[\mathrm{M}(\mathrm{L})_{2} \cdot\left(\mathrm{H}_{2} \mathrm{O}\right)_{\mathrm{n}}\right] \cdot \mathrm{Z} \cdot m \mathrm{H}_{2} \mathrm{O}$ за $\mathrm{L}=\mathrm{L} 1$ и $\mathrm{L} 2,\left[\mathrm{M}(\mathrm{L}) \cdot\left(\mathrm{H}_{2} \mathrm{O}\right)_{\mathrm{n}}\right] \cdot 2 \mathrm{Z} \cdot m \mathrm{H}_{2} \mathrm{O}$ за $\mathrm{L}=\mathrm{L} 3\left(\mathrm{Z}=\mathrm{Cl}^{-}\right.$за $\mathrm{M}=\mathrm{La}(\mathrm{III})$ и $\mathrm{Z}$ 
$=\mathrm{NO}_{3}^{-}$за $\mathrm{M}=\mathrm{Ce}(\mathrm{III})$ и $\left.\mathrm{Nd}(\mathrm{III})\right)$. Комплексите со $\mathrm{Nd}(\mathrm{III})-\mathrm{L} 3$ покажуваат задоволителна каталитичка активност при аеробна оксидација на $p$-фенилендиамин (PPD) до соодветната семиоксидирана форма $\left(\mathrm{PPD}^{+}\right)$. Дискутирана и тестирана е антимикробната активност на комплексите. Моделирана е и симулирана молекуларната структура и енергија на образуваните комплекси со програмскиот пакет ChemOffice. Проценета е врската меѓу просторниот распоред на образуваните комплекси и нивната антимикробна активност.

Клучни зборови: комплекси на лантаноид(III) јоните во цврста фаза; каталитичка активност; антибактериски особини; термички особини и спроводливост;

моделирање на молекуларна структура

\section{INTRODUCTION}

The chemistry of pyrazole derivatives has aroused much interest due to their versatile application in medicine and biological activities [1]. Pyrazole and substituted pyrazoles are pharmaceutical reagents used as inhibitors and deactivators of liver alcohol dehydrogenase [2-4]. Some pyrazole derivatives have been used as insecticides [5], thermally stable materials $[6,7]$ and as cotton azo-dyes $[8,9]$. The lanthanide complexes of some Schiff bases which have luminescence properties could be used as sensor for many applications purposes. The main species formed in aqueous solutions containing some Schiff bases have been determined by analysis of the luminescence spectra, lifetimes of $\mathrm{Eu}(\mathrm{III})$ excited states and vibronic interaction as well as structural features of the $\mathrm{Eu}(\mathrm{III})$ coordination sphere. The potential application of the lanthanide complexes as new luminescence materials have been discussed [10]. Also, some Schiff base complexes have been used as promising catalysts which could be applied as green chemistry reagents [11]. Recently, lanthanide complexes derived from some Schiff bases were used in DNA cleavage which could find pharmaceutical use [12]. Five-coordinate lanthanide complexes derived from some Schiff bases have been prepared and characterized [13].

The synthesis and the physicochemical properties of the ligands under investigation (L1, L2 and L3) were previously reported [14]. However, a literature survey has indicated that no work has been done on the synthesis of lanthanide(III) complexes derived from these ligands. Accordingly, the present study involves the physicochemical properties of the synthesized solid com- plexes derived from these ligands and $\mathrm{La}(\mathrm{III})$, $\mathrm{Ce}(\mathrm{III})$ and $\mathrm{Nd}(\mathrm{III})$ metal ions. The catalytic behavior of these complexes was tested towards the aerobic oxidation of $p$-phenylenediamine (PPD). Furthermore, the biological activity was tested using some Gram-positive and Gram-negative bacteria and the relationship between the structure and the activity will be discussed.

\section{EXPERIMENTAL}

\subsection{Chemicals}

The ligands 2,4-dihydroxybenzylidene3'-imino-5'-methylpyrazole (L1); salicylidene3'-imino-5'-methylpyrazole (L2) and 2-hydroxynaphthylidene-3'-imino-5'-methyl-pyrazole (L3) were prepared as described previously [14]. The metal salts were obtained from Aldrich. All reagents were of AR grade. All organic solvents were of analytical grade and used without extra purification.

\subsection{Preparation of complexes}

All the complexes were prepared by mixing 2:1 stoichiometric amounts of the ligand (2 mmol, $0.434 \mathrm{~g}$ for L1, $0.402 \mathrm{~g}$ for L2 and $0.503 \mathrm{~g}$ for L3) in hot ethanol $\left(20 \mathrm{~cm}^{3}\right)$ and metal ions (1 $\mathrm{mmol}$ ) in hot ethanol (minimal amount). The prepared metal salt solution was added dropwise to the ligand solution with stirring, and the mixture was refluxed for one hour. The solid complexes formed after partial evaporation of the solvent. The precipitated complexes were then removed by filtration, washed with ethanol and $\mathrm{Et}_{2} \mathrm{O}$ and dried in vacuum.- 
The antimicrobial activities were measured by the hole diffusion method. Five mm wells were made in Czapek's agar medium using a stainless steel cork borer. The wells were filled with the tested substances $(50 \mathrm{ppm})$. The medium was seeded with propagules of either the Gram-negative bacteria (Escherichia coli and Pseudomonas aeruginasa) or Gram-positive bacteria (Bacillus subtilis and Staphyllococcus aureus) as testing microorganisms. The compound is considered effective if it inhibits the growth of the testing microorganism. This was determined by the clear zone shown around the wells measured in $\mathrm{mm}$ (diameter of the zone). Wells containing either solvent alone or distilled water served as a control.

\subsection{Instrumentation}

$\mathrm{C}, \mathrm{H}$ and $\mathrm{N}$ were measured using $\mathrm{CHN}$ Rapid Fa. Heraeus analyzer, each measurement was repeated twice. Thermal analyses (DTA/ TGA) were carried out using a Shimadzu DTA50 instrument using a platinum cell under a dynamic flow of nitrogen at a heating rate of $10^{\circ} \mathrm{C}$ $\mathrm{min}^{-1}$. Electrical conductivity measurements were carried out at $25{ }^{\circ} \mathrm{C}$ on freshly prepared $10^{-3} \mathrm{M}$ DMSO solution using a WTW conductivity meter model LF-42 fitted with a LTA-100 conductivity cell. IR spectra were recorded in the range 4000$400 \mathrm{~cm}^{-1}$ in $\mathrm{KBr}$ discs on a Perkin-Elmer 883 spectrophotometer. UV/Vis spectra were measured at room temperature on a Beckman model 5260 spectrophotometer in $1 \mathrm{~cm}$ quartz cells. Mass spectra of the complexes were obtained using a Varian mass spectrometer model MAT711, by using electron energy of $70 \mathrm{eV}$ and final temperature of $250-300^{\circ} \mathrm{C}$.

\section{RESULTS AND DISCUSSION}

\subsection{General properties}

The formed solid complexes from the reactions of L1, L2 and L3 (Scheme 1) with $\mathrm{LaCl}_{3}, \mathrm{Ce}\left(\mathrm{NO}_{3}\right)_{3}$ and $\mathrm{Nd}\left(\mathrm{NO}_{3}\right)_{3}$ in ethanol-water medium gave 1:2 (metal : ligand) complexes for L1 and L2, while L3 gave 1:1 complexes.

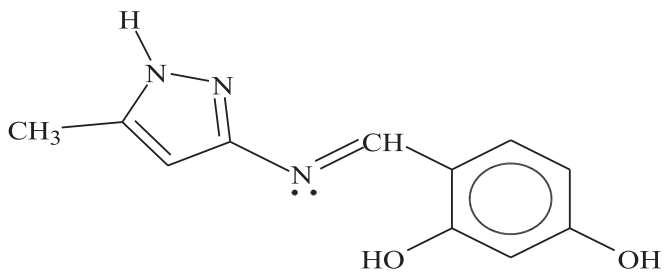

2,4-dihydroxybenzylidene-3'-imino-5'-methylpyrazole

(L1)

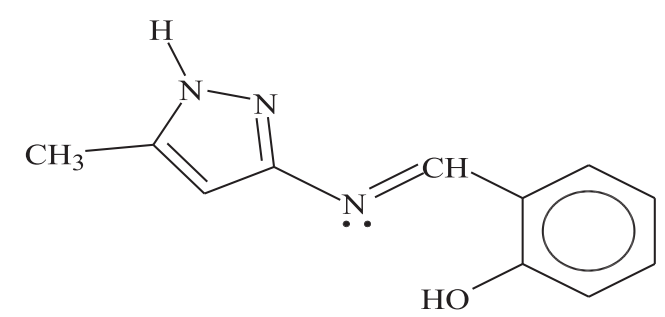

Salicylidene-3'-imino-5'-methylpyrazole (L2)

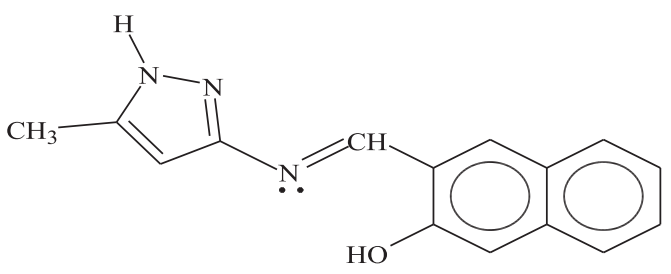

2-hydroxynaphthylidene-3'-imino-5' -methylpyrazole (L3)

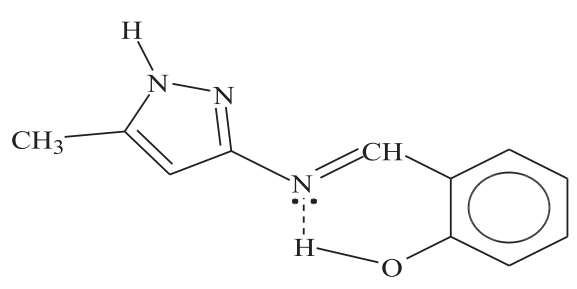

Intrahydrogen bond structure

Scheme 1. The IUPAC name and configuration of the L1, L2 and L3 ligands

The formed complexes could be formulated as: $\left[\mathrm{M}(\mathrm{L})_{2} \cdot\left(\mathrm{H}_{2} \mathrm{O}\right)_{\mathrm{n}}\right] \cdot \mathrm{Z} \cdot m \mathrm{H}_{2} \mathrm{O}$ for $\mathrm{L}=\mathrm{L} 1$ and $\mathrm{L} 2$, $\left[\mathrm{M}(\mathrm{L}) \cdot\left(\mathrm{H}_{2} \mathrm{O}\right)_{n}\right] \cdot 2 \mathrm{Z} \cdot m \mathrm{H}_{2} \mathrm{O}$ for $\mathrm{L}=\mathrm{L} 3$, where $(\mathrm{M})$ represent the metal ion, $(n)$ and $(m)$ are variable numbers for each complex, while $\mathrm{Z}=\mathrm{Cl}^{-}$or $\mathrm{NO}_{3}^{-}$. The complexes were yellow, pale orange, greenish yellow non-hygroscopic powders, soluble in methanol, ethanol, dimethylsulfoxide (DMSO) and dimethylformamide (DMF), but insoluble in acetone, benzene and ether (Table 1). The puri- 


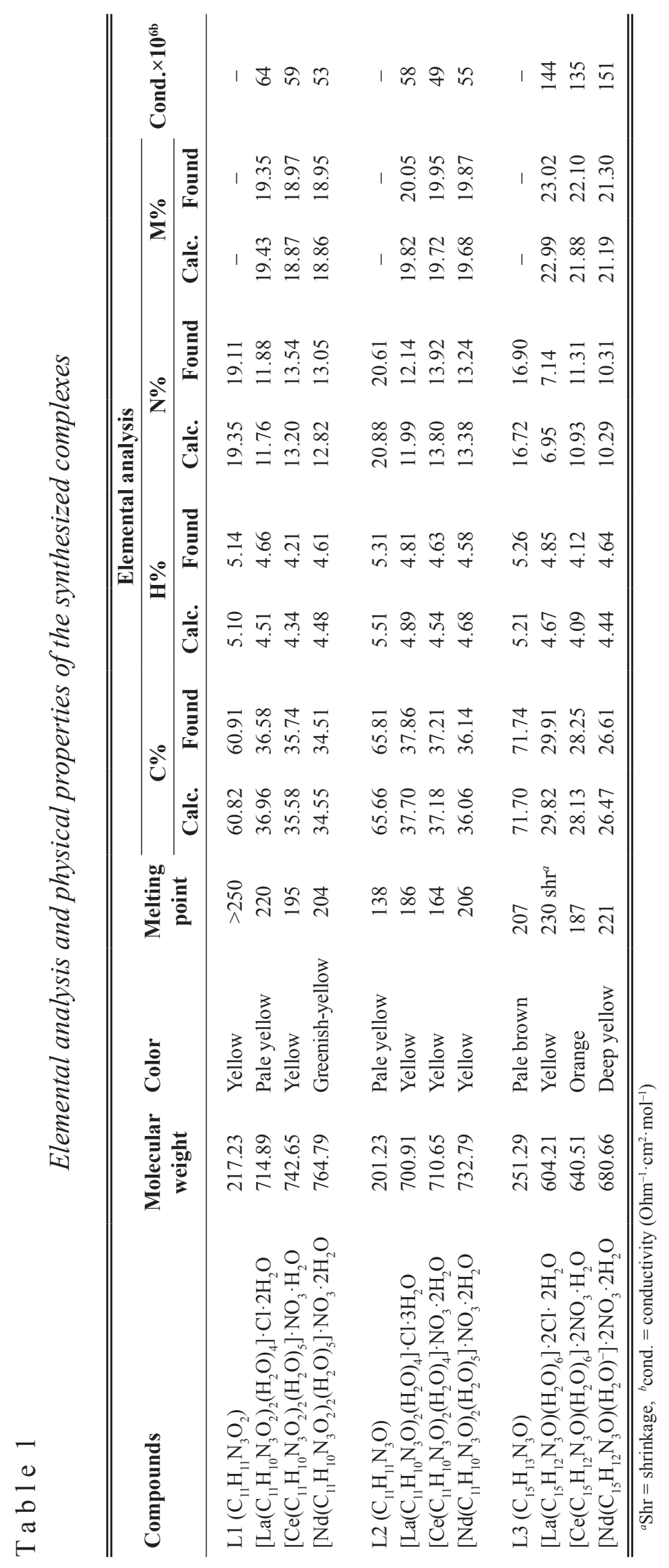

Maced. J. Chem. Chem. Eng. 32 (1), 25-39 (2013) 
ties were confirmed by chemical analysis, melting point and TLC (silica gel GF 254 type 60, mesh size 50-250, eluted with $\mathrm{H}_{2} \mathrm{O}$-ethanol).

\subsection{Electrical conductivity}

The molar conductance of the formed complexes in DMSO (Table 1) indicated that, they act as good electrolytes $[15,16]$. The values of the conductivity (Table 1) could be represented as [A]B species for M(III)-L1 and M(III)-L2 complexes, while $\mathrm{M}(\mathrm{III})-\mathrm{L} 3$ gave $[\mathrm{A}] \cdot 2 \mathrm{~B}$ species (A $=$ coordination sphere, $\mathrm{B}=\mathrm{Cl}^{-}$or $\mathrm{NO}_{3}^{-}$as ionization sphere) [17].

\subsection{Infrared spectra}

The main IR bands and their assignment are listed in Table 2. Significant frequencies were selected by comparing the IR spectra of the free ligands with those of the metal complexes [14]. The band at $3740-2500 \mathrm{~cm}^{-1}$ range, present in all complexes as a broad band, indicates the presence of water molecules which exist in the coordination and ionization sphere. This fact was also indicated by the results of the elemental and thermal analysis. The sharp band present at 3283, 3281, 3282 $\mathrm{cm}^{-1}$ for $\mathrm{La}(\mathrm{III})-\mathrm{L} 1, \mathrm{Ce}(\mathrm{III})-\mathrm{L} 1$ and $\mathrm{Nd}(\mathrm{III})-\mathrm{L} 1$ complexes respectively, indicates the presence of the phenolic $\mathrm{O}-\mathrm{H}$ (in para position) without complexation. The absorption peaks of the $\mathrm{C}-\mathrm{O}$ bond observed in the $1356-1322 \mathrm{~cm}^{-1}$ region in the spectra of the free ligands [14] are moved to higher wavenumber and became weaker in the spectra of the complexes. This supports bonding of the metal ions to the phenolic $\mathrm{O}-\mathrm{H}$ after deprotonation [18-20]. Since the $\mathrm{OH}$ group is located at the ortho-position relative to the central $\mathrm{C}=\mathrm{N}$, it can be predicted that, the nitrogen of this bond, and not of the pyrazole ring, is involved in the complex formation, which gives a stable six-membered chelate ring [18]. The spectra of the pyrazole ring which gave nearly no change to slightly blue shift in the complexes compared to the parent ligands [14] could be attributed to the sharing effect of the chelated metal ion on the stretching vibration of this ring. A strong band found in $1608-1600 \mathrm{~cm}^{-1}$ in the spectra of the complexes could be assigned as $\mathrm{C}=\mathrm{N}$ stretching vibration [21]. The observed shift in the $\mathrm{C}=\mathrm{N}$ stretching vibration confirms the formation of a certain bond between the imine nitrogen and the metal ion [14, 21]. Meanwhile the relatively low shift supports the following points: (1) lanthanide metal ions are

Table 2

Characteristic IR spectral data of the ligands and their complexes

\begin{tabular}{lcccccc}
\hline \hline Compounds & $v\left(\mathrm{H}_{2} \mathrm{O}\right)$ & $v(\mathrm{OH}, \mathrm{NH}, \mathrm{CH})$ & $v(\mathrm{C}=\mathrm{N})$ & $v(\mathrm{C}-\mathrm{O})$ & $v(\mathrm{MO})$ & $v(\mathrm{MN})$ \\
\hline $\mathrm{L} 1\left(\mathrm{C}_{11} \mathrm{H}_{11} \mathrm{~N}_{3} \mathrm{O}_{2}\right)$ & & $3284 \mathrm{~s}, 3180-2900 \mathrm{br}$ & $1611 \mathrm{~s}$ & $1333 \mathrm{vs}$ & - & - \\
{$\left[\mathrm{La}\left(\mathrm{C}_{11} \mathrm{H}_{10} \mathrm{~N}_{3} \mathrm{O}_{2}\right)_{2}\left(\mathrm{H}_{2} \mathrm{O}\right)_{4}\right] \cdot \mathrm{Cl} \cdot 2 \mathrm{H}_{2} \mathrm{O}$} & $3680-2500 \mathrm{br}{ }^{a}$ & $3283 \mathrm{sh}$ & $1608 \mathrm{~m}$ & $1341 \mathrm{w}$ & $535 \mathrm{w}$ & $435 \mathrm{w}$ \\
{$\left[\mathrm{Ce}\left(\mathrm{C}_{11} \mathrm{H}_{10} \mathrm{~N}_{3} \mathrm{O}_{2}\right)_{2}\left(\mathrm{H}_{2} \mathrm{O}\right)_{5}\right] \cdot \mathrm{NO}_{3} \cdot \mathrm{H}_{2} \mathrm{O}$} & $3685-2520 \mathrm{br}$ & $3281 \mathrm{sh}$ & $1610 \mathrm{~s}$ & $1340 \mathrm{~m}$ & $533 \mathrm{w}$ & $424 \mathrm{w}$ \\
{$\left[\mathrm{Nd}\left(\mathrm{C}_{11} \mathrm{H}_{10} \mathrm{~N}_{3} \mathrm{O}_{2}\right)_{2}\left(\mathrm{H}_{2} \mathrm{O}\right)_{5}\right] \cdot \mathrm{NO}_{3} \cdot 2 \mathrm{H}_{2} \mathrm{O}$} & $3681-2525 \mathrm{br}$ & $3282 \mathrm{sh}$ & $1609 \mathrm{~m}$ & $1374 \mathrm{~m}$ & $536 \mathrm{w}$ & $427 \mathrm{w}$ \\
& & & & & & \\
$\mathrm{L} 2\left(\mathrm{C}_{11} \mathrm{H}_{11} \mathrm{~N}_{3} \mathrm{O}\right)$ & - & $3380-2950 \mathrm{br}$ & $1622 \mathrm{~s}$ & $1356 \mathrm{w}$ & - & - \\
{$\left[\mathrm{La}\left(\mathrm{C}_{11} \mathrm{H}_{10} \mathrm{~N}_{3} \mathrm{O}\right)_{2}(\mathrm{H} \mathrm{O})_{4}\right] \cdot \mathrm{Cl}_{3} \cdot 3 \mathrm{H}_{2} \mathrm{O}$} & $3680-2510 \mathrm{br}$ & - & $1610 \mathrm{~s}$ & $1396 \mathrm{w}$ & $515 \mathrm{w}$ & $475 \mathrm{w}$ \\
{$\left[\mathrm{Ce}\left(\mathrm{C}_{11} \mathrm{H}_{10} \mathrm{~N}_{3} \mathrm{O}\right)_{2}\left(\mathrm{H}_{2} \mathrm{O}\right)_{4}\right] \cdot \mathrm{NO}_{3} \cdot 2 \mathrm{H}_{2} \mathrm{O}$} & $3682-2508 \mathrm{br}$ & - & $1609 \mathrm{~s}$ & $1392 \mathrm{~s}$ & $513 \mathrm{w}$ & $480 \mathrm{w}$ \\
{$\left[\mathrm{Nd}\left(\mathrm{C}_{11} \mathrm{H}_{10} \mathrm{~N}_{3} \mathrm{O}\right)_{2}\left(\mathrm{H}_{2} \mathrm{O}\right)_{5}\right] \cdot \mathrm{NO}_{3} \cdot 2 \mathrm{H}_{2} \mathrm{O}$} & $3685-2513 \mathrm{br}$ & - & $1610 \mathrm{~s}$ & $1385 \mathrm{~s}$ & $510 \mathrm{w}$ & $482 \mathrm{w}$ \\
& & - & & & & - \\
$\mathrm{L} 3\left(\mathrm{C}_{15} \mathrm{H}_{13} \mathrm{~N}_{3} \mathrm{O}\right)$ & - & $3340-2930 \mathrm{br}$ & $1617 \mathrm{~m}$ & $1339 \mathrm{~m}$ & - & - \\
{$\left[\mathrm{La}\left(\mathrm{C}_{15} \mathrm{H}_{12} \mathrm{~N}_{3} \mathrm{O}\right)\left(\mathrm{H}_{2} \mathrm{O}\right)_{6}\right] \cdot 2 \mathrm{Cl}_{2} \cdot 2 \mathrm{H}_{2} \mathrm{O}$} & $3725-2522 \mathrm{br}$ & - & $1609 \mathrm{~m}$ & $1285 \mathrm{~m}$ & $550 \mathrm{w}$ & $467 \mathrm{w}$ \\
{$\left[\mathrm{Ce}\left(\mathrm{C}_{15} \mathrm{H}_{12} \mathrm{~N}_{3} \mathrm{O}\right)\left(\mathrm{H}_{2} \mathrm{O}\right)_{6}\right] \cdot 2 \mathrm{NO}_{3} \cdot \mathrm{H}_{2} \mathrm{O}$} & $3686-2500 \mathrm{br}$ & - & $1600 \mathrm{~m}$ & $1374 \mathrm{~m}$ & $552 \mathrm{w}$ & $470 \mathrm{w}$ \\
{$\left[\mathrm{Nd}\left(\mathrm{C}_{15} \mathrm{H}_{12} \mathrm{~N}_{3} \mathrm{O}\right)\left(\mathrm{H}_{2} \mathrm{O}\right)_{7}\right] \cdot 2 \mathrm{NO}_{3} \cdot 2 \mathrm{H} \mathrm{O}$} & $3740-2514 \mathrm{br}$ & - & $1600 \mathrm{~m}$ & $1385 \mathrm{~m}$ & $555 \mathrm{w}$ & $476 \mathrm{w}$ \\
\hline \hline
\end{tabular}

${ }^{a} \mathrm{br}$ - broad, $\mathrm{s}$ - strong, vs- very strong, $\mathrm{m}$ - medium, $\mathrm{sh}$ - shoulder, $\mathrm{w}$ - weak 
more oxygen favorable than nitrogen, (2) enhance the presence of intrahydrogen bond in the ligands formed between the lone pair of nitrogen electrons of the $\mathrm{C}=\mathrm{N}$ group and the hydrogen of the $\mathrm{OH}$ group in the ortho-position (Scheme 1). The appearance of two new bands at low frequency ranges at $555-510 \mathrm{~cm}^{-1}$ and $482-424 \mathrm{~cm}^{-1}$ are assigned as $v(\mathrm{M}-\mathrm{O})$ and $v(\mathrm{M}-\mathrm{N})$, respectively, supporting chelation through the oxygen and nitrogen atoms [17, 21] (Table 2).

\subsection{DTA/TG analysis}

The application of TGA and DTA to evaluate solid-state reactions involving weight loss (or gain) has been studied by a number of researchers $[22,23]$. The measurements were carried out in the temperature range $25-400{ }^{\circ} \mathrm{C}$. The thermal analysis data of the solid complexes (Table 3) (Figures 1-3 as example) gave rise to the following observations:

T a b 1 e 3

The thermal gravimetric analysis data for the synthesized complexes

\begin{tabular}{|c|c|c|c|c|c|}
\hline \multirow{2}{*}{ Complexes } & \multirow{2}{*}{$T\left({ }^{\circ} \mathrm{C}\right)$} & \multicolumn{2}{|c|}{ Weight loss $\%$} & \multirow{2}{*}{ Peak type } & \multirow[t]{2}{*}{ Assignment } \\
\hline & & Found & Calculate & & \\
\hline \multirow[t]{4}{*}[\mathrm{La}(\mathrm{Ll})_{2}(\mathrm{H}_{2}\mathrm{O})_{4}]{$\cdot \mathrm{Cl} \cdot 2 \mathrm{H}_{2} \mathrm{O}$} & 93 & 5.41 & 5.04 & Endo & Water of crystallization $\left(2 \mathrm{H}_{2} \mathrm{O}\right)$ \\
\hline & 143 & 9.73 & 10.08 & Endo & Coordinated water $\left(4 \mathrm{H}_{2} \mathrm{O}\right)$ \\
\hline & 241 & 5.03 & 5.11 & Endo & $\mathrm{HCl}$ liberation \\
\hline & 323 & - & - & Exo & Solid state reaction \\
\hline \multirow{3}{*}[\mathrm{Ce}(\mathrm{L}1)_{2}(\mathrm{H}_{2}\mathrm{O})_{5}]{$\cdot \mathrm{NO}_{3} \cdot \mathrm{H}_{2} \mathrm{O}$} & 102 & 2.33 & 2.43 & Endo & Water of crystallization $\left(\mathrm{H}_{2} \mathrm{O}\right)$ \\
\hline & 152 & 12.40 & 12.13 & Endo & Coordinated water $\left(5 \mathrm{H}_{2} \mathrm{O}\right)$ \\
\hline & 361 & 8.01 & 8.48 & Exo & $\mathrm{HNO}_{3}$ liberation \\
\hline \multirow{3}{*}[\mathrm{Nd}(\mathrm{L}1)_{2}(\mathrm{H}_{2}\mathrm{O})_{5}]{$\cdot \mathrm{NO}_{3} \cdot 2 \mathrm{H}_{2} \mathrm{O}$} & 113 & 4.92 & 4.71 & Endo & Water of crystallization $\left(2 \mathrm{H}_{2} \mathrm{O}\right)$ \\
\hline & 158 & 12.20 & 11.78 & Endo & Coordinated water $\left(5 \mathrm{H}_{2} \mathrm{O}\right)$ \\
\hline & 348 & 8.40 & 8.24 & Exo & $\mathrm{HNO}_{3}$ liberation \\
\hline \multirow{3}{*}[\mathrm{La}(\mathrm{L}2)_{2}(\mathrm{H}_{2}\mathrm{O})_{4}]{$\cdot \mathrm{Cl} \cdot 3 \mathrm{H}_{2} \mathrm{O}$} & 83 & 7.82 & 7.71 & Endo & Water of crystallization $\left(3 \mathrm{H}_{2} \mathrm{O}\right)$ \\
\hline & 132 & 10.35 & 10.28 & Endo & Coordinated water $\left(4 \mathrm{H}_{2} \mathrm{O}\right)$ \\
\hline & 230 & 5.11 & 5.21 & Exo & $\mathrm{HCl}$ liberation \\
\hline \multirow{3}{*}[\mathrm{Ce}(\mathrm{L}2)_{2}(\mathrm{H}_{2}\mathrm{O})_{4}]{$\cdot \mathrm{NO}_{3} \cdot 2 \mathrm{H}_{2} \mathrm{O}$} & 89 & 5.23 & 5.07 & Endo & Water of crystallization $\left(2 \mathrm{H}_{2} \mathrm{O}\right)$ \\
\hline & 141 & 10.32 & 10.14 & Endo & Coordinated water $\left(4 \mathrm{H}_{2} \mathrm{O}\right)$ \\
\hline & 339 & 8.76 & 8.87 & Exo & $\mathrm{HNO}_{3}$ liberation \\
\hline \multirow[t]{3}{*}[\mathrm{Nd}(\mathrm{L}2)_{2}(\mathrm{H}_{2}\mathrm{O})_{5}]{$\cdot \mathrm{NO}_{3} \cdot 2 \mathrm{H}_{2} \mathrm{O}$} & 94 & 5.11 & 4.92 & Endo & Water of crystallization $\left(2 \mathrm{H}_{2} \mathrm{O}\right)$ \\
\hline & 150 & 12.36 & 12.29 & Endo & Coordinated water $\left(5 \mathrm{H}_{2} \mathrm{O}\right)$ \\
\hline & 349 & 8.66 & 8.60 & Exo & $\mathrm{HNO}_{3}$ liberation \\
\hline \multirow[t]{3}{*}[\mathrm{La}(\mathrm{L}3)(\mathrm{H}_{2}\mathrm{O})_{6}]{$\cdot 2 \mathrm{Cl} \cdot 2 \mathrm{H}_{2} \mathrm{O}$} & 70 & 6.21 & 5.96 & Endo & Water of crystallization $\left(2 \mathrm{H}_{2} \mathrm{O}\right)$ \\
\hline & 168 & 17.96 & 17.89 & Endo & Coordinated water $\left(6 \mathrm{H}_{2} \mathrm{O}\right)$ \\
\hline & 263 & 11.91 & 12.08 & Exo & 2HCl liberation \\
\hline \multirow[t]{3}{*}[\mathrm{Ce}(\mathrm{L}3)(\mathrm{H}_{2}\mathrm{O})_{6}]{$\cdot 2 \mathrm{NO}_{3} \cdot \mathrm{H}_{2} \mathrm{O}$} & 65 & 3.02 & 2.81 & Endo & Water of crystallization $\left(\mathrm{H}_{2} \mathrm{O}\right)$ \\
\hline & 161 & 16.69 & 16.88 & Endo & Coordinated water $\left(6 \mathrm{H}_{2} \mathrm{O}\right)^{2}$ \\
\hline & 357 & 19.82 & 19.67 & Exo & $2 \mathrm{HNO}_{3}$ liberation \\
\hline \multirow[t]{3}{*}[\mathrm{Nd}(\mathrm{L}3)(\mathrm{H}_{2}\mathrm{O})_{7}]{$\cdot 2 \mathrm{NO}_{3} \cdot 2 \mathrm{H}_{2} \mathrm{O}$} & 68 & 5.38 & 5.29 & Endo & Water of crystallization $\left(2 \mathrm{H}_{2} \mathrm{O}\right)$ \\
\hline & 156 & 18.71 & 18.53 & Endo & Coordinated water $\left(7 \mathrm{H}_{2} \mathrm{O}\right)$ \\
\hline & 370 & 18.64 & 18.51 & Exo & $2 \mathrm{HNO}_{3}$ liberation \\
\hline
\end{tabular}




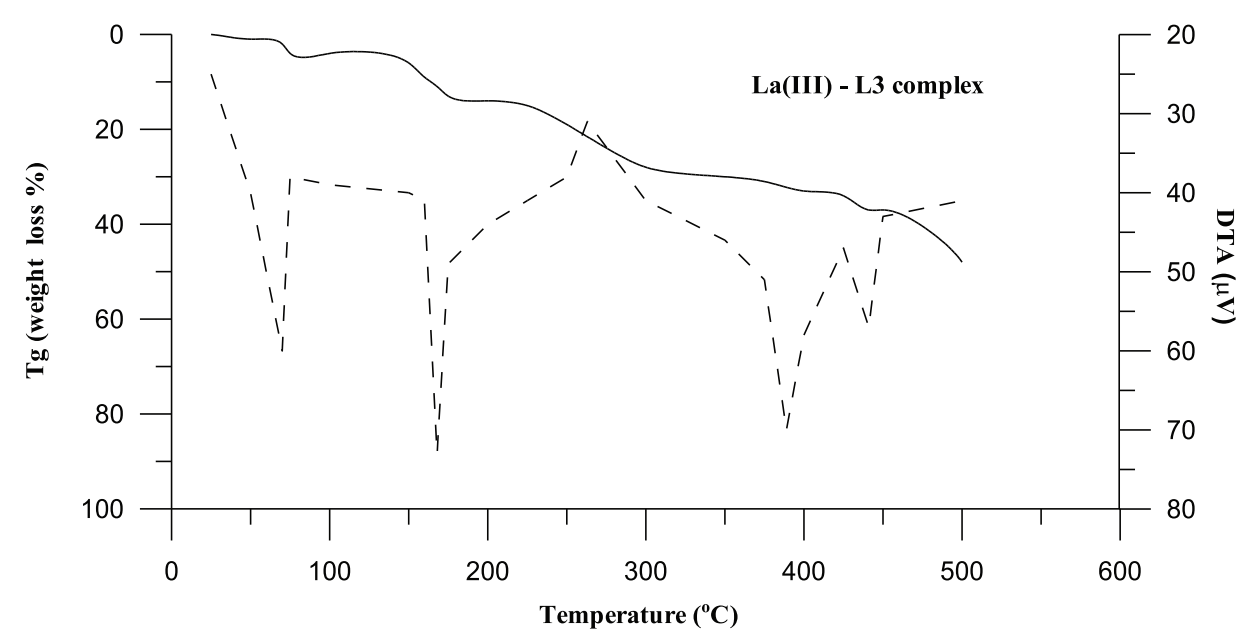

Fig. 1. DTA (- - - ) and TGA ( - ) diagram for La(III) - L3 complex

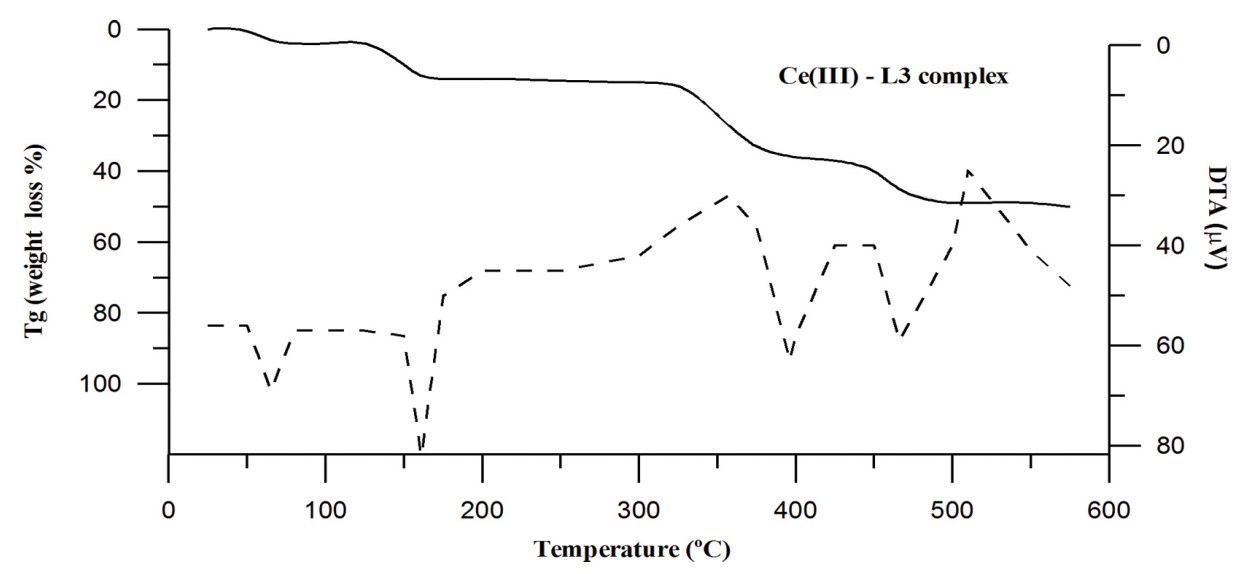

Fig. 2. DTA (- - - ) and TGA (- - diagram for Ce(III) - L3 complex

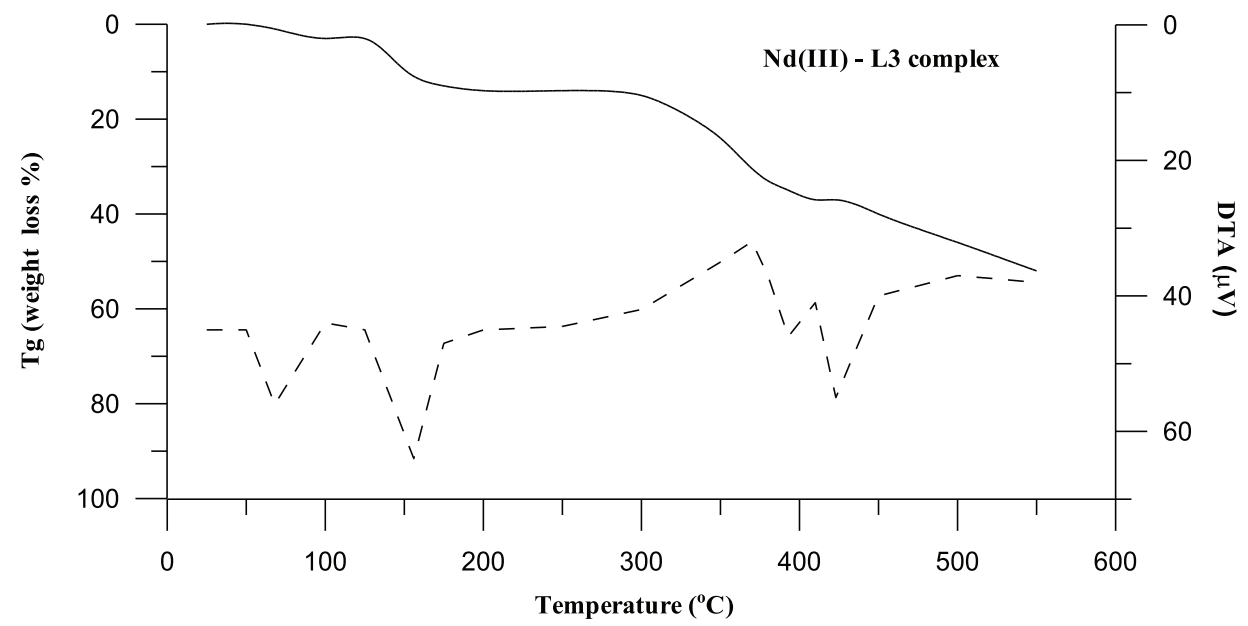

Fig. 3. DTA (- - - ) and TGA (- $)$ diagram for Nd(III) - L3 complex 
1. All complexes gave endothermic peak in the $65-113^{\circ} \mathrm{C}$ range accompanied by weight loss in the TGA diagram which could be denoted as liberation of water of crystallization; the percent weight loss transformed to the number of water molecules as shown in Table 3. The thermal stability order of this type of water is as follows:

a) M(III)-L1 complexes > M(III)-L2 complexes $>\mathrm{M}(\mathrm{III})-\mathrm{L} 3$ complexes

b) $\mathrm{La}(\mathrm{III})-\mathrm{L}$ complexes $<\mathrm{Ce}(\mathrm{III})-\mathrm{L}$ complexes $<\mathrm{Nd}(\mathrm{III})-\mathrm{L}$ complexes when $\mathrm{L}=$ L1 and L2, while L3 gave the following order: $\mathrm{La}(\mathrm{III})-\mathrm{L} 3$ complexes $>\mathrm{Ce}(\mathrm{III})-$ L3 complexes $<\mathrm{Nd}$ (III)-L3 complexes

2. The endothermic peak centered at $130-158$ ${ }^{\circ} \mathrm{C}$ range for all complexes could be due to the liberation of the coordinated water molecules [24, 25]. M(III)-L3 complexes gave the largest thermal stability $\left(156-168^{\circ} \mathrm{C}\right)$ compared to $\mathrm{M}(\mathrm{III})-\mathrm{L} 1\left(143-158^{\circ} \mathrm{C}\right)$ and M(III)-L2 (132-150 $\left.{ }^{\circ} \mathrm{C}\right)$. Therfore the thermal stability of the coordinated water could be as follows: M(III)-L3 > M(III)-L2 $\leq$ M(III)-L1 complexes. The thermal stability trends of the complexes with respect to the metal ions is in the following order: $\mathrm{Nd}(\mathrm{III})$ $>\mathrm{Ce}(\mathrm{III})>\mathrm{La}(\mathrm{III})$ for L1 and L2 ligands, whereas with L3 has the following trend: $\mathrm{La}(\mathrm{III})>\mathrm{Ce}(\mathrm{III})>\mathrm{Nd}(\mathrm{III})$. The percent weight loss in TG diagram corroborate the postulated structure of the M(III)-L complexes (Scheme 2).

3. $\mathrm{La}(\mathrm{III})-\mathrm{L}$ complexes gave extra exothermic peaks at 241,230 and $263{ }^{\circ} \mathrm{C}$ for $\mathrm{L}=\mathrm{L} 1$, L2 and L3, respectively. The percent of the weight loss indicates that at these temperatures the $\mathrm{HCl}$ molecules could be liberated [18].

4. The $\mathrm{NO}_{3}^{-}$group could be liberated as $\mathrm{HNO}_{3}$ for $\mathrm{Ce}(\mathrm{III})-\mathrm{L}$ and $\mathrm{Nd}$ (III)-L complexes with exothermic peaks at temperature ranges $\left(348-361^{\circ} \mathrm{C}\right),\left(339-349^{\circ} \mathrm{C}\right)$ and $(357-370$ ${ }^{\circ} \mathrm{C}$ ) for $\mathrm{L}=\mathrm{L} 1, \mathrm{~L} 2$ and $\mathrm{L} 3$, respectively [17, $18]$.

\subsection{Mass spectra}

The mass spectra of the complexes under investigation gave the molecular ion peak as $\left(\left[\mathrm{M}(\mathrm{L} 1)_{2}\right] \cdot \mathrm{Z}\right)^{+},\left(\left[\mathrm{M}(\mathrm{L} 2)_{2}\right] \cdot \mathrm{Z}\right)^{+}$and $([\mathrm{ML} 3] \cdot 2 \mathrm{Z})^{+}$ (where $\mathrm{Z}=\mathrm{Cl}^{-}$when $\mathrm{M}=\mathrm{La}(\mathrm{III})$ and $\mathrm{Z}=\mathrm{NO}_{3}^{-}$ when $\mathrm{M}=\mathrm{Ce}(\mathrm{III})$ or $\mathrm{Nd}(\mathrm{III})$ ) (Table 4). Each molecular ion peak could be accompanied by some extra peaks which depends on the occurrence of the isotopes of each atom in the formed complexes and their abundance. As a result, the molecular ion peak and the molecular ion peak +2 for $\mathrm{Ce}$ (III) complexes clearly appeared due to presence of the predominant isotopes of the $\mathrm{Ce}(\mathrm{III})[\mathrm{Ce}(140)$ $88.48 \%$ and $\mathrm{Ce}(142) 11.08 \%$ ]. On the other hand, $\mathrm{Nd}(\mathrm{III})$ complexes gave the molecular ion peak, molecular ion +2 and +4 due to the isotopes $\mathrm{Nd}(142) 24.13 \%, \mathrm{Nd}(144) 23.80 \%$ and $\mathrm{Nd}(146) 17.19 \%$, respectively. The absence of the other seven isotopes was maybe due to their lower abundance $[\mathrm{Nd}(143) \quad 12.18 \%, \mathrm{Nd}(145)$ 8.30\%, $\mathrm{Nd}(148) 5.76 \%$ and $\mathrm{Nd}(150) 5.64 \%$ ]. The absence of the $\mathrm{H}_{2} \mathrm{O}$ molecules in the molecular ion peak, could be atrtributed to the measurement conditions (carried out at $\mathrm{T}=200$ ${ }^{\circ} \mathrm{C}$ ). The $m / z$ value for the molecular ion peaks and other fragment peaks gave strong support to the postulated structures of the solid complexes under consideration [26, 27] (Scheme 2). Generally, the similarity of the fragments of the $\mathrm{La}-\mathrm{L}, \mathrm{Ce}-\mathrm{L}$ and $\mathrm{Nd}-\mathrm{L}(\mathrm{L}=\mathrm{L} 1, \mathrm{~L} 2)$ complexes could be attributed to the similarity of the structure of these complexes, while a different behavior was found for the M-L3 complexes. The stepwise fragmentation of the $\mathrm{La}-\mathrm{L} 1$ complex was postulated as an example (Figure 4 ). The charges on the fragments were omitted for simplification.

The $m / z$ values for the molecular ion peaks, thermal analysis, the elemental analysis (C, H, N, M), conductivity measurements and the IR spectra could be represented the structure of the synthesized complexes as shown in Scheme 2. 

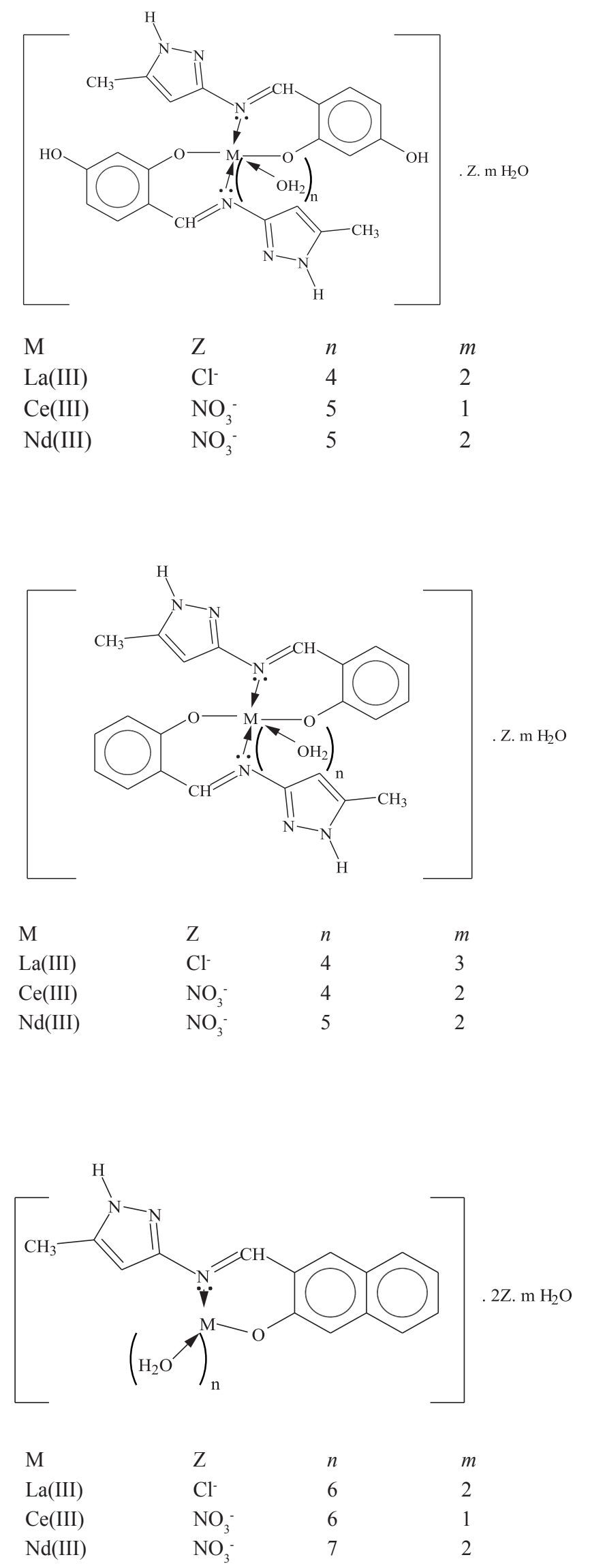

Scheme 2. The postulated structure of the $\mathrm{M}(\mathrm{III})-\mathrm{L}$ complexes
Table 4

The most significant $(\mathrm{m} / \mathrm{z})$ for the mass spectra of the synthesized compounds

\begin{tabular}{lll}
\hline \hline Complex & $m / z(\%)$ & Assignment \\
\hline La(III)-L1 & $608(6), 607(15)$ & $\left(\left[\mathrm{La}(\mathrm{L} 1)_{2}\right] \cdot \mathrm{Cl}\right)^{+}$ \\
Ce(III)-L1 & $635(8)$ & $\left(\left[\mathrm{Ce}(\mathrm{L} 1)_{2}\right] \cdot \mathrm{NO}_{3}\right)^{+}$ \\
Nd(III)-L1 & $643(7), 641(10), 639(11)$ & $\left(\left[\mathrm{Nd}(\mathrm{L} 1)_{2}\right] \cdot \mathrm{NO}_{3}\right)^{+}$ \\
La(III)-L2 & $576(4), 575(7)$ & $\left(\left[\mathrm{La}(\mathrm{L} 2)_{2}\right] \cdot \mathrm{Cl}\right)^{+}$ \\
Ce(III)-L2 & $603(10)$ & $\left(\left[\mathrm{Ce}(\mathrm{L} 2)_{2}\right] \cdot \mathrm{NO}_{3}\right)^{+}$ \\
Nd(III)-L2 & $611(4), 609(7), 607(8)$ & $\left(\left[\mathrm{Nd}(\mathrm{L} 2)_{2}\right] \cdot \mathrm{NO}_{3}\right)^{+}$ \\
La(III)-L3 & $462(6), 461(5), 460(8)$ & $\left([\mathrm{LaL} 3] \cdot 2 \mathrm{Cl}^{+}\right.$ \\
Ce(III)-L3 & $515(18)$ & $\left([\mathrm{CeL} 3] \cdot 2 \mathrm{NO}_{3}\right)^{+}$ \\
Nd(III)-L3 & $521(10), 519(11), 517(8)$ & $\left([\mathrm{NdL} 3] \cdot 2 \mathrm{NO}_{3}\right)^{+}$ \\
\hline \hline
\end{tabular}

\subsection{Catalytic activity}

The catalytic activity of the $\mathrm{Nd}(\mathrm{III})-\mathrm{L} 3$ complex was investigated in respect to the aerobic oxidation of the one-electron oxidation system of $p$-phenylenediamine (PPD) to the corresponding oxidized form $\mathrm{PPD}^{+}$(Wurster's salt). The obtained $\mathrm{PPD}^{+}$has an appreciable $t_{1 / 2}$ in methanol and absorbs strongly in the visible region with $\lambda_{\max }$ at $460 \mathrm{~nm}$ [28-30]. The catalytic oxidation reaction was followed spectrophotometrically by monitoring the increase in $\mathrm{PPD}^{+}$ absorbance at $460 \mathrm{~nm}$ as a function of time. Plots of the absorbance versus time are linear. The slope of the line is equal to the reaction rate constant, $k$. The oxidase catalytic activity (OCA) of the examined complexes obtained as $\%$ PPD oxidation $\left(\% \mathrm{PPD}^{+}\right.$formed) calculated from the absorbance ratio of the sample $(\Delta 1)$ to the control $(\Delta 2)$ (without metal complex) as:

$$
\% \mathrm{OCA}=\left[\Delta 1-\frac{\Delta 2}{\Delta 1}\right] \times 100
$$

The absorbance of $\mathrm{PPD}^{+}$was followed after the oxidation of PPD with a solution of the complexes under investigation. The $\mathrm{Nd}(\mathrm{III})$-L3 complex gave a rate constant, $k=$ $6.3 \times 10^{-3}\left(\mathrm{M}^{-1} \mathrm{~s}^{-1}\right)$, with $\mathrm{OCA}=73$. The obtained results could be rationalized as follows: 


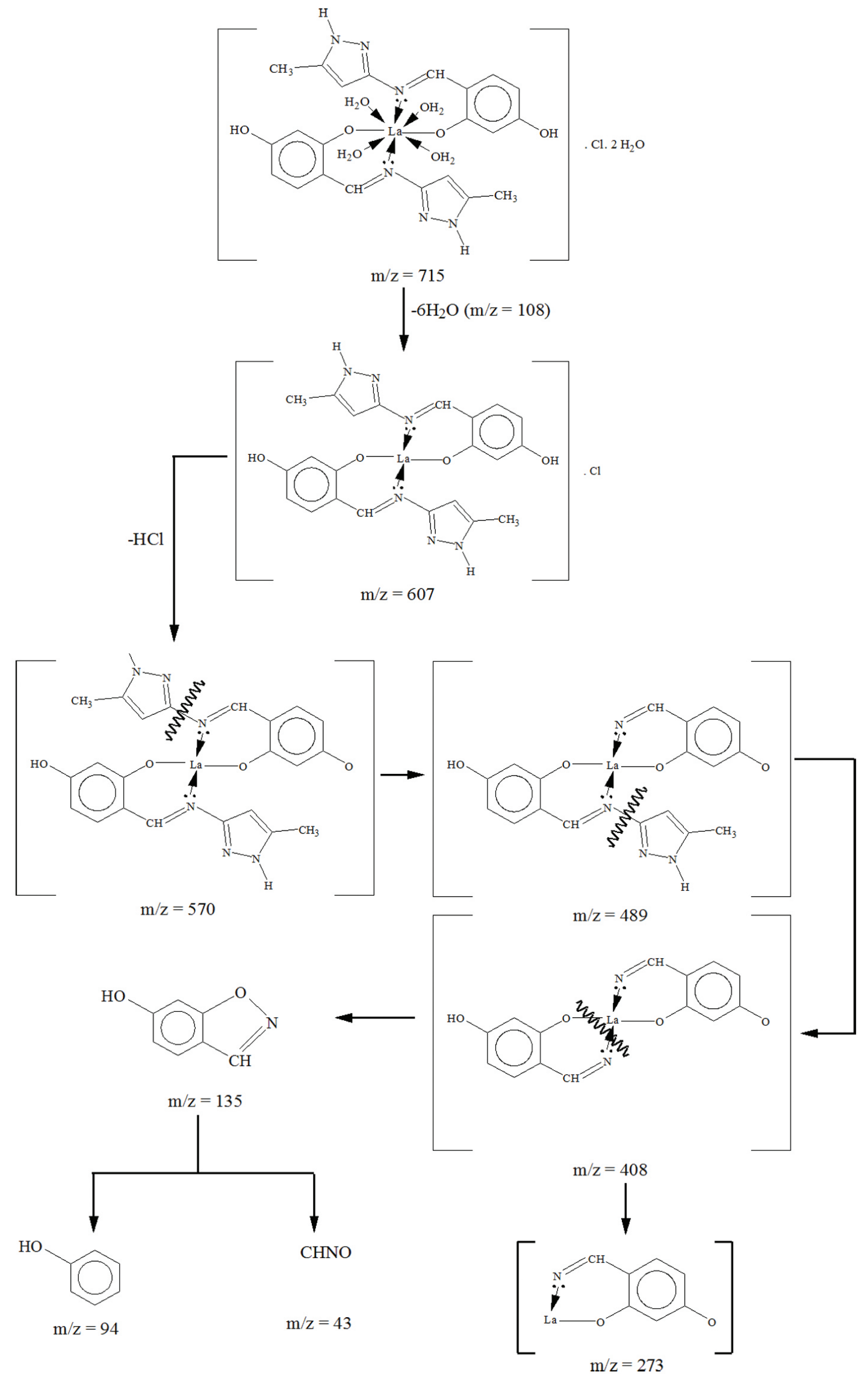

Fig. 4. The postulated fragments of the $\mathrm{La}(\mathrm{III})-\mathrm{L} 1$ complex 
Introduction of PPD to the $\mathrm{Nd}(\mathrm{III})-\mathrm{L} 3$ complex which bonds with $\mathrm{Nd}$ (III).

1. Then PPD reduces the $\mathrm{Nd}(\mathrm{III})$ to $\mathrm{Nd}(\mathrm{II})$ and forms $\mathrm{PPD}^{+}$which separates from the complex.

2. Simultaneously, the $\mathrm{PPD}^{+}$absorption appears and the further increase of the PPD band can be explained by a slow oxidation of the $\mathrm{Nd}(\mathrm{II})$ by air oxygen.

3. The $\mathrm{Nd}(\mathrm{III})$ complex is re-reduced immediately to $\mathrm{Nd}$ (II) complex which produces $\mathrm{PPD}^{+}$again, as long as PPD is present.

Generally the previous steps depend on the Lewis acidity of the central metal ion and the $\mathrm{M}(\mathrm{II}) / \mathrm{M}(\mathrm{III})$ redox potential [31].

\subsection{Biological activities}

Several pyrazole and pyrazoline substitution products are used in medicine [1]. Generally, the binding of metal ions with organic ligands enhances the biological activities of these ligands $[32,33]$. The antimicrobial activity of the complexes derived from the ligands under consideration with $\mathrm{Cu}(\mathrm{II}), \mathrm{Ni}(\mathrm{II})$ and $\mathrm{Co}(\mathrm{II})$ have been tested. The tested complexes were not antimicrobially active [18]. Recently, Gd(III) complexes have often been used in clinical MRI to increase the contrast by selectively relaxing the water molecules near the complex; Eu(III) gave nearly the same effect. Due to the importance of the lanthanide metal ions in contemporary clinical systems, we wanted to test the activity of the lanthanide complexes on the biological system.

The $\mathrm{La}(\mathrm{III}), \mathrm{Ce}(\mathrm{III})$ and $\mathrm{Nd}$ (III) complexes under investigation were tested as antibacterial active agents using $50 \mathrm{ppm}$ concentration in ethanolic medium. The Gram-negative bacteria used were Escherichia coli and Pseudomonas aeruginasa, and Gram-positive bacteria were Bacillus subtilis and Staphyllococcus aureus. The obtained activities are shown in Table 5. The free metal ions and free ligands were inactive under the same experimental conditions. The obtained data could be discussed collectively as the follows:

1. The M(III)-L3 complexes have the largest activity followed by M(III)-L1 and finally M(III)-L2, so they could be arranged as: M(III)-L3 > M(III)-L1 > M(III)-L2.

2. The complexes under investigation have greater activity towards the Gram-negative bacteria (Escherichia coli and Pseudomonas aeruginasa) than to Gram-positive bacteria (Bacillus subtilis and Staphyllococcus aureus).

3. Collectively, the Nd(III)-L complexes gave the greaterst activity with respect to the other complexes and could be arranged as: Nd(III)-L > Ce(III)-L > La(III)-L.

T a b l e 5

Antibacterial activities of the synthesized compounds

\begin{tabular}{lcccc}
\hline \hline \multirow{2}{*}{ Compound } & \multicolumn{2}{c}{ Gram-positive bacteria } & \multicolumn{2}{c}{ Gram-negative bacteria } \\
\cline { 2 - 5 } & B. subtilis & S. aureus & E. coli & P. aeruginosa \\
\hline La(III)-L1 & 7 & 7 & 8 & 15 \\
Ce(III)-L1 & 8 & 7 & 7 & 9 \\
Nd(III)-L1 & 7 & 16 & 7 & 18 \\
\hline $\mathrm{La}(\mathrm{III})-\mathrm{L} 2$ & 7 & 5 & 7 & 5 \\
$\mathrm{Ce}(\mathrm{III})-\mathrm{L} 2$ & 5 & 5 & 8 & 7 \\
$\mathrm{Nd}(\mathrm{III})-\mathrm{L} 2$ & 5 & 8 & 7 & 7 \\
\hline $\mathrm{La}(\mathrm{III})-\mathrm{L} 3$ & 14 & 8 & 18 & 9 \\
$\mathrm{Ce}(\mathrm{III})-\mathrm{L} 3$ & 16 & 17 & 17 & 16 \\
$\mathrm{Nd}(\mathrm{III})-\mathrm{L} 3$ & 18 & 8 & 19 & 18 \\
\hline \hline
\end{tabular}


The greatest activity of the M(III)-L3 complexes maybe due to the greater ionic character of these complexes, which could be represented as $[\mathrm{A}]^{2+} \cdot 2 \mathrm{~B}^{-}$type and this form could facilitate the penetration of these compounds through the lipoid layers of the microorganism membrane as lipophilic reagents [1, 34]. Also, these complexes have minimum steric effect compared to the M(III)-L1 and M(III)-L2 complexes, which leads to easier penetration of the bacteria wall. The Nd(III)-L1 gave high activity toward $S$. aureus (Gram-positive) and $P$. aeruginosa (Gram-negative) larger than toward B. subtilis and E. coli - this could lead to a particular complex design specific towards these bacteria, however the reason needs extensive work from bactriolegests. The activity was found in the low active range (6-9 $\mathrm{mm})$ to moderate active $(15-19 \mathrm{~mm})$ at the concentration used (50 ppm). Generally, the $\mathrm{Nd}$ (III) gave the largest activity, maybe due to the high electronegativity and the smallest size, compared to $\mathrm{La}(\mathrm{III})$ and $\mathrm{Ce}(\mathrm{III})[1,34]$.

\subsection{Molecular mechanical calculation (MM2) and molecular modeling}

Molecular mechanics (CS Chem3D 7.0 as a stand alone application within the package program CS ChemOffice) describes the energy of a molecule in terms of a set of classically derived potential energy functions. The potential energy functions and the parameters used for their evaluation are known as a "force-field". Molecular mechanics typically treats atoms as spheres, and bonds as springs. The mathematics of spring deformation (Hooke's law) is used to describe the ability of bonds to stretch, bend, and twist. Non-bonded atoms (greater than two bonds apart) interact through Van der Waals attraction, steric repulsion, and electrostatic attraction/repulsion. These properties are easiest to describe mathematically when atoms are considered as spheres of characteristic radii. The total potential energy of a molecule can be described by the following summation of interactions [35-37]. Total Energy $=$ Stretching Energy + Bending Energy + Torsion Energy + Non-Bonded Interaction Energy. The molecular mechanics MM2 force fields method, with minimum RMS gradient $=0.1$ was used to improve: (a) The Energy Minimization for locating stable conformations, (b) Single point energy calculations for comparing conformations of the same molecule.

Table 6 and Figure 5, shows the results which obtained from the MM2 calculations which carried out on the different spatial arrangement of the synthesized complexes to obtain the most stable structure which give the

T a b 1 e 6

The types and the values of energy which evaluated from the molecular modeling calculation

\begin{tabular}{lccc}
\hline \hline Energy type & {$\left[\mathrm{La}(\mathrm{L} 1)_{2} \cdot\left(\mathrm{H}_{2} \mathrm{O}\right)_{4}\right]^{1+}$} & {$\left[\mathrm{La}(\mathrm{L} 2)_{2} \cdot\left(\mathrm{H}_{2} \mathrm{O}\right)_{4}\right]^{1+}$} & {$\left[\mathrm{La}(\mathrm{L} 3) \cdot\left(\mathrm{H}_{2} \mathrm{O}\right)_{6}\right]^{2+}$} \\
\hline Stretching & $76.27^{a}$ & 78.35 & 148.28 \\
Bending & 59.13 & 57.56 & 64.46 \\
Stretching-bending & -1.43 & -1.42 & -4.16 \\
Torsion & 189.80 & 188.53 & 184.98 \\
Non-1,4VDW & -7.95 & -8.30 & -4.14 \\
1,4VDW & 164.45 & 163.88 & 156.28 \\
Dipole/Dipole & 3.97 & 4.06 & 16.87 \\
\hline Total energy & 484.23 & 482.66 & 562.58 \\
\hline \hline \multicolumn{2}{l}{ The units are kcal/mole for all energy types. The values of the energy terms shown here are } \\
approximate and can vary slightly based on the type of processor used to calculate them.
\end{tabular}




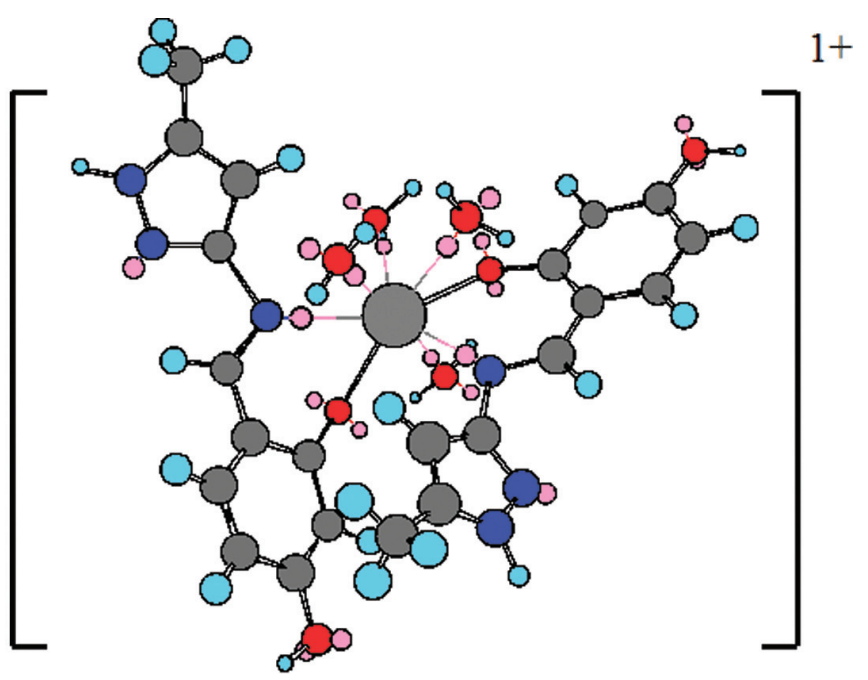

(a)

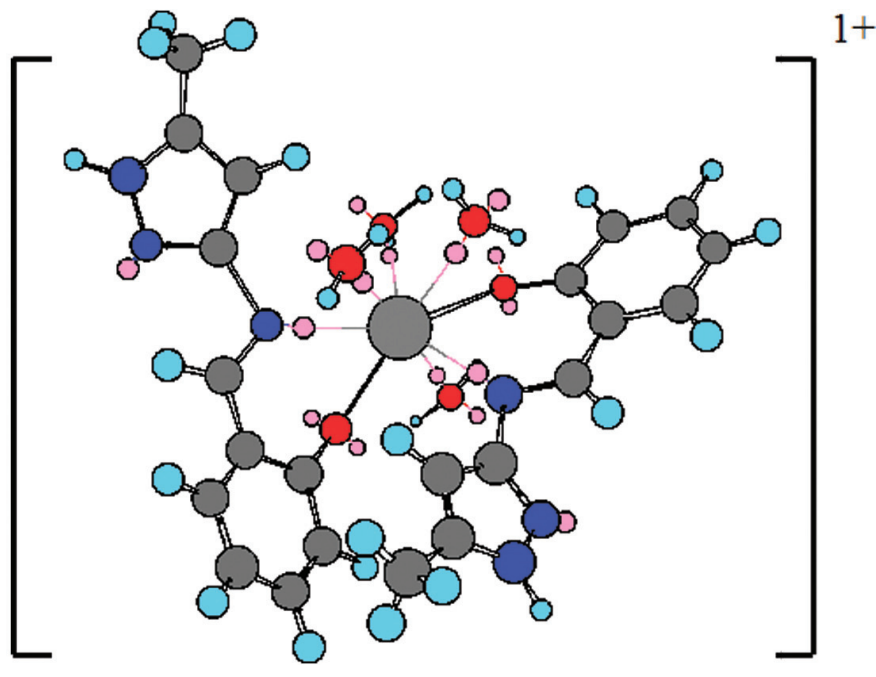

(b)

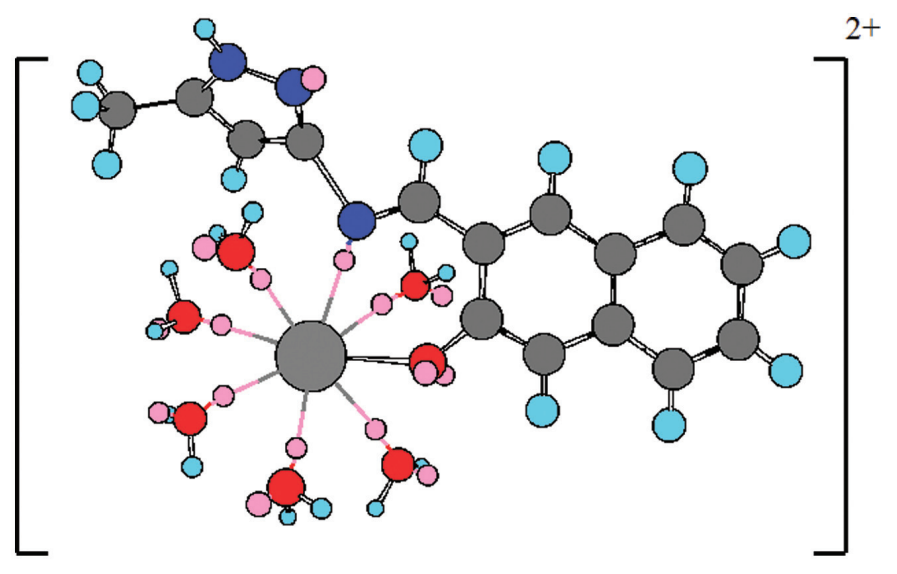

Fig. 5. The MM2 calculated structure of the La(III) - L complexes, where (a): $\mathrm{L}=\mathrm{L} 1$, (b): $\mathrm{L}=\mathrm{L} 2$ and $(\mathrm{c}): \mathrm{L}=\mathrm{L} 3$ least total energy using the job type: Minimize Energy to Minimum RMS Gradient of 0.100 . The values of the total energy were found to be at $482.66-562.58 \mathrm{kcal} / \mathrm{mol}$ range for complexes derived from $\mathrm{La}$ (III) ions (as representative example). The torsion and the 1,4VDW parameters could be assigned as the predominate energies which indicating the high energy for the through-space interaction of atoms separated by two atoms (more than two bonds) [35-38]. The total steric energy order for the coordination sphere for the synthesized La(III)-L complexes could be arranged as the following:

$$
\text { La(III)-L3 > La(III)-L1 } \geq \text { La(III)-L2 }
$$

Collectively, the values of the different types of the energy for all complexes are nearly similar, with some exception for the stretching and dipole/dipole interaction for the $\mathrm{La}(\mathrm{III})-$ L3 which has the largest value (Table 6). The increasing of the dipole/dipole energy which in consequence increasing the polarity of the complexes beside the larger ionic charge $(2+)$ for the La(III)-L3 complex enhancement the penetration of the compounds through the cell membrane of the cell of the microorganism which translated to the higher biological activity. From the MM2 calculation and molecular modeling work, could be formulated the coordination sphere of the complexes under investigation as shown in the Figure 5, which supports the postulated structures obtained previously from the experimental works (Scheme 2 and Figure 4).

\section{CONCLUSIONS}

L1 and L2 gave 1:2 (metal : ligand) ratio complexes while L3 gave 1:1 ratio complexes. All formed complexes are non-hygroscopic powders, soluble in polar solvents and conduct electricity which can give rise to versatile choices in their applications. The M(III)-L1 complexes have the highest thermal stability. The Nd(III)-L3 complex gave a pronounced catalytic activity towards the aerobic oxidation 
of the one-electron oxidation system of $p$-phenylenediamine (PPD) to the corresponding oxidized form $\mathrm{PPD}^{+}$. The M(III)-L complexes have antimicrobial activity in the following order: M(III)-L3 > M(III)-L1 > M(III)-L2. The $\mathrm{Nd}(\mathrm{III})-\mathrm{L}$ complexes showed the largest activity compared to the other complexes and could be arranged as: $\mathrm{Nd}(\mathrm{III})-\mathrm{L}>\mathrm{Ce}(\mathrm{III})-\mathrm{L}>$ $\mathrm{La}(\mathrm{III})-\mathrm{L}$. The MM2 calculation reveal that, the total steric energy for the coordination sphere for the synthesized $\mathrm{La}(\mathrm{III})-\mathrm{L}$ decreased as follows: $\mathrm{La}$ (III)-L3 $>\mathrm{La}$ (III)-L1 $\geq \mathrm{La}$ (III)-L2 . The well defined structure and the properties of the complexes under investigation give rise to the idea about using these complexes as thermal and/or bio-sensors and also in industrial applications such as catalytic reagent for some reactions.

\section{REFERENCES}

[1] J. N. Delgado, W. A. Remers, Textbook of Organic Medicinal and Pharmaceutical Chemistry, Williams and Wilkins, USA, $10^{\text {th }}$ edition, 1998, pp. 722-723 and refs therin.

[2] D. E. Feierman, A. I. Cederbaum, Inhibition of microsomal oxidation of ethanol by pyrazole and 4-methylpyrazole in vitro. Increased effectiveness after induction by pyrazole and 4-methylpyrazole, Biochem. J., 239, 671-677 (1986).

[3] S. R. Stauffer, C. J. Coletta, R. Tedesco, G. Nishiguchi, K. Carlson, J. Sun, B. S. Katzenellenbogen, J. A. Katzenellenbogen, Pyrazole ligands: structure-affinity/activity relationships and estrogen receptor-alpha-selective agonists, $J$. Med. Chem., 43(26), 4934-4947 (2000).

[4] C. Zitt, B. Strauss, E. C. Schwarz, N. Spaeth, G. Rast, A. Hatzelmann, M. Hoth, Potent inhibition of $\mathrm{Ca}^{2+}$ release-activated $\mathrm{Ca}^{2+}$ channels and T-lymphocyte activation by the pyrazole derivative BTP2, J. Biol. Chem., 279(13), 12427-12437 (2004).

[5] C. Grossvcut, R. van Hes, K. Wellinga, 1-Phenylcarbamoyl-2-pyrazolines, a new class of insecticides. 3. Synthesis and insecticidal properties of 3,4-diphenyl-1-phenylcarbamoyl-2-pyrazolines, J. Agric. Food Chem., 27(2), 406-409 (1979).
[6] B. Barszcz, M. Gabryszewski, K. Kulig, B. J. Lenarcik, Potentiometric studies on complexes of silver(I) in solutions. Part 2. Correlation between the stability of the silver(I)-azole complexes and the ligand basicity, J. Chem. Soc. Dalton Trans., 2025-2028 (1986).

[7] M. D. Ward, J. S. Fleming, E. Psillakis, J. C. Jeffery, J. A. McCleverty, $\left[\mathrm{Pd}(\mathrm{HL} L) \mathrm{Cl}_{2}\right]$ and $\left[\mathrm{Pd} L_{2}\right]$, where $\mathrm{HL}$ is 2-(3-Pyrazolyl)pyridine, Acta Crys., C54, 609-612 (1998).

[8] C. Klein, E. Baranoff, M. Grätzel, Md.K. Nazeeruddin, Convenient synthesis of tridentate 2,6-di(pyrazol-1-yl)-4-carboxypyridine and tetradentate 6,6'-di(pyrazol-1-yl)-4,4'-dicarboxy2,2'-bipyridine ligands, Tetrahedron Letters, 52(5), 584-587 (2011).

[9] R. Katritsky, C. W. Rees, Comprehensive Heterocyclic Chemistry. The Structure, Reaction, Synthesis and Uses of Heterocyclic Compounds, Pergamon Press, 1984, pp. 49-50 and 167-304.

[10] L. Puntus, K. Zhuravlev, K. Lyssenko, M. Antipin, I. Pekareva, Luminescence and structural properties of lanthanide complexes of Schiff bases derived from pyridoxal and amino acids, Dalton Trans., 4079-4088 (2007).

[11] P. G. Cozzi, Metal-salen Schiff base complexes in catalysis: practical aspect, Chem. Soc. Rev., 33, 410-421 (2004).

[12] A. Kulkami, S. A. Patil, P. S. Badami, Synthesis, characterization, DNA cleavage and in vitroantimicrobial studies of $\mathrm{La}(\mathrm{III}), \mathrm{Th}(\mathrm{IV})$ and VO(IV) complexes with Schiff bases of coumarin derivatives, European J. of Med. Chem., 44(7), 29042912 (2009).

[13] S. A. Schuetz, C. M. Silvermail, C. D. Incarvito, A. L. Rheingold, J. L. Clark, V. W. Day J. A. Belot, Mononuclear, five-coordinate lanthanide amido and aryloxide complexes bearing tetradentate $\left(\mathrm{N}_{2} \mathrm{O}_{2}\right)$ Schiff bases, Inorg. Chem., 43(20), 62036214 (2004).

[14] Sh. A. Sallam, A. S. Orabi, Formation Constant of Lanthanon(III) Complexes of Some Schiff-Bases Derived from 3-Amino-5-Methylpyrazole, Egypt. J. Chem., 47(4), 383-400 (2004).

[15] W. J. Geary, The use of conductivity measurements in organic solvents for the characterization of coordination compounds, Coord. Chem. Rev., 7, 81-122 (1971). 
[16] A. S. Orabi, Physicochemical Properties of Some New Uranyl Complexes Derived from Acetone Derivatives Ligands, Monatshefte für Chemie, 129, 1139-1149 (1998).

[17] A. S. Orabi, Complexes derived from some biologically active ligands, J. Coord. Chem., 61(8), 1294-1305 (2008).

[18] Sh. A. Sallam, Synthesis, characterization and thermal decomposition of copper(II), nickel(II) and cobalt(II) complexes of 3-amino-5-methylpyrazole Schiff-bases, Trans. Met. Chem., 30, 341-351 (2005).

[19] A. Syamal, New antiferromagnetic copper(II) complexes with some dibasic tridentate ONS donor Schiff bases, Trans. Met. Chem., 5, 220-222 (1980).

[20] V. Patel, K. Desai, T. Thaker, Mixed Azomethine Mononuclear and Binuclear Copper (II) Complexes with Alkyl and Aryl Schiff Bases Involving ONO and ONS Donor Atoms, Synth. React. Inorg. Met.-Org. Chem., 19, 391-412 (1989).

[21] K. Nakamoto, Infrared and Raman Spectra of Inorganic and Coordination Compounds, John Wiley \& Sons, New York, USA, $3^{\text {rd }}$ edition, 1992.

[22] K. Bahgat, A. S. Orabi, Physical characteristics, vibrational spectroscopy and normal-coordinate analysis of 2-aminophenol and 2-phenylenediamine complexes, Polyhedron, 21, 987-996 (2002).

[23] S. Ibrahim, S.A. Sallam, A. S. Orabi, B. A. ElShetary ,A. Lentz, A. Schiff Bases of Acetone Derivatives: Spectroscopic Properties and Physical Constants, Monatshefte für Chemie, 129, 159-171 (1998).

[24] A. S. Orabi, F. S. Deghaidy, H. A. Azab, H. Said, Physico-chemical Properties of Nd(III) and Er(III) Complexes with Some Biological Buffer Ligands, Synth. React. Inorg. Met.-Org. Chem., 31(4), 695712 (2001).

[25] T. H. Rakha, A. A. El-Asmy, M. M. Mostafa, A. El-Kourshy, Synthesis and structural studies on bivalent metal complexes of benzenesulphonylhydrazine, Trans. Met. Chem., 12(2), 125-127 (1987).

[26] R. M. Silverstein, G. C. Bassler, T. C. Morrill, Spectrometric Identification of Organic Com- pounds, John Wiley and Sons, New York, USA, $5^{\text {th }}$ edition, 1991.

[27] S. Celebi, Y. Ozkalay, Y. Sarikahya, IR Sudies on Salicylaldehyde Azine Schiff Base and Some of its Metal Complexes, Spektrosk. Derg., 22-33 (1986).

[28] A. S. Orabi, M. I. Ayad, A. M. Ramadan, Synthesis, characterization and oxidase catalytic activity of Vanadium(IV) and oxovanadium(IV) complexes with Schiff base ligands derived from $\beta$-diketones, Trans. Met. Chem., 23, 391-396 (1998).

[29] H. H. Jaffe, M. Orchin, Theory and Application of Ultraviolet Spectroscopy, Wiley, London, 1962, p. 464.

[30] U. Nickel, E. Hosse, B. Thormann, The reduction mechanism of peroxodisulfate, studied by it's reaction with $p$-phenylenedi-amines, Zeitschrift fuer Physikalische Chemie, 170(1-2), 159-183 (1991).

[31] J. Recdijk, Bioinorganic Catalysis, Marcel Dekker, New York, USA, 1993, ch.11 and 13.

[32] S. J. Lippard, J. M. Berg, Principles of Bioinorganic Chemistry, University Books, USA, 1994, pp. 1-41.

[33] R. J. P. Williams, Bio-inorganic chemistry: its conceptual evolution, Coord. Chem. Rev., 100, 573610 (1990).

[34] Z. H. Chohan, M. A. Farooq, Synthesis, characterization, ligational and biological properties of some acylhydrazine derived furanyl and thienyl Schiff bases with $\mathrm{Co}(\mathrm{II}), \mathrm{Cu}(\mathrm{II}), \mathrm{Ni}(\mathrm{II})$, and $\mathrm{Zn}(\mathrm{II})$ metal ions, Synthesis and Reactivity in Inorganic and Metal-Organic Chemistry, 31(10), 1853-1871 (2001).

[35] A. Gavezotti, G. Filippini, Geometry of the intermolecular X-H...Y (X,Y=N,O) hydrogen bond, and the calibration of empirical hydrogen-bond parameters, J. Phys. Chem., 98, 4831-4837 (1994).

[36] N. L. Allinger, Y. H. Yuh, J. H. Lii, Molecular mechanics, the MM3 force field for hydrocarbons, $J$. Am. Chem. Soc., 111(23), 8551-8566 (1989).

[37] T. Schlick, Molecular Modeling and Simulation: An Interdisciplinary Guide Interdisciplinary Applied Mathematics: Mathematical Biology, Springer-Verlag, New York, USA, 2000.

[38] A. S. Orabi, Mercury complexes derived from some acetone derivatives ligands, AFINIDAD, LXVII, 557, 53-61 (2012). 
